\title{
THE REVIEW OF REWORK CAUSES AND COSTS IN HOUSING CONSTRUCTION SUPPLY CHAIN
}

\author{
Mehdi Shahparvari ${ }^{1}$ and Daniel Fong ${ }^{2}$
}

\begin{abstract}
Rework in construction projects can cause significant waste of cost and time. Within lean construction practice, rework minimisation is of most interest among project managers. However, less attention has been paid to investigating rework reduction or avoidance in the housing supply chain. Given the increasing costs incurred due to rework generation, innovative approaches to reduce and avoid rework throughout the housing supply chain has never been more urgently required. Elaborating the root causes of rework is essential as it clearly highlights the role of various supply chain contributors. This paper investigates the root causes of rework in construction projects in general and in housing projects in particular. More specifically, the impact of rework on the entire housing supply chain will be explained.
\end{abstract}

\section{KEYWORDS}

Rework reduction, Housing Construction, Lean Construction, Housing Supply Chain, Lean Strategies.

\section{INTRODUCTION}

The UK housing supply chain has often been criticised for the poor quality and performance of its products and the inadequacy of its production process (Pan, et al., 2008). The Construction industry in 2014 , contributed around $£ 100$ billion to the UK economy (equivalent to $7 \%$ of the GDP), from which the housing sector contribution was approximately 40\%. Traditionally, the UK housing construction industry has not improved its productivity to deliver such value, and it has been one of the largest construction economic challenges encountering the UK construction industry.

Construction is one of the major industries worldwide and is commonly recognised as having high levels of 'waste'. The term 'waste' is defined as 'anything that is not

1 PhD Student, Division of Construction, Property \& Surveying, School of Engineering and the Built Environment. London South Bank University, SE1 0AA, United Kingdom, +44 (0) 7753444327 , shahparm@1sbu.ac.uk

2 Associate Professor, Division of Construction, Property \& Surveying, School of the Built Environment and Architecture, London South Bank University, SE1 0AA, United Kingdom, fongd@1sbu.ac.uk 
required to create value for the customer/client or end-user. Therefore, it can be viewed as something of a paradox that waste reduction has not become a dominant strategy with regard to improving productivity in this industry (Bolviken and Koskela, 2016).

The elimination of waste has been essentially used as a key driver for improvement in the manufacturing industry. However, despite its great achievement, it has not been as prevalent in the construction practice and literature (Koskela, et al., 2012).

After introducing the lean concept to the construction industry in1992 by Koskela, there were many attempts and practices to implement Lean Construction (LC) across the industry to eliminate 'waste' and add 'value' to the projects. Nevertheless, there has been a lack of clarity within the construction sector surrounding the concept of LC. Yet the majority of the industry has failed to implement LC (Bolviken and Koskela, 2016).

One of the major 'wastes' in housing construction projects is 'rework'. The term 'rework' describes the work that has to be done for a second time. Rework affects both the costs and schedule throughout the project. Construction sites have complex environments which multiple trades and suppliers need to work at the same time and with different business objectives. In such environments, the likelihood of errors and mistakes wouldoccur. The cost of rework in construction projects has been estimated as high as $12 \%$ of the contract value, which can be a large amount of the revenue (Love and Edwards, 2005; Burati, et al., 1992).

\section{COST OF REWORK IN CONSTRUCTION PROJECTS}

Almost all the existing cost estimates for rework are expressed as a percentage of the total project cost (Taggart, et al., 2014). Recent studies by Love and Li (2000), Love, et al. (2004) and Hwang, et al. (2009) indicate that rework costs ranges from 2-6\% during construction and an additional 3-5\% during the maintenance. Love (2002) suggests that many of these costs are hidden in the process and could possibly be near to $25 \%$ of the total. These rework issues normally are generated in one part of the process, but they are often not detected until a later stage, thus increasing the costs (Koskela, et al., 2006).

In Egan's (1998) report on the UK construction industry, he indicated that $30 \%$ of construction cost is related to rework. The USA based Construction Industry Institute has projected that the loss of rework can be as high as $\$ 15$ billion for industrial construction projects (Rogge, et al., 2001). Egan's (1998) Rethinking Construction report, highlights that a $20 \%$ annual reduction in the number of defects at handover is required as a driver of sustained improvement (Sommerville, 2007). Moreover, there have been several reports that suggest rework can be found at different locations around the world in counties, such as; Australia (Love, et al., 1999), China (Kumaraswamy and Dissanayaka, 2000), and Chile (Serpell, et al., 2000) meaning that these countries are confronting mutual problems (Sommerville, 2007).

The financial and economic impact of rework in construction varies widely per project, with costs reaching up to $70 \%$ of the total project costs. Love and Edwards (2004) showed that earlier work on rework might result in less costs (that is between $3 \%$ and $15 \%$ of a project's contract value). Barber, et al. (2000) reported that rework cost might 
be as high as $23 \%$ of a contract value. Simpeh, et al. (2015) on the other hand found that the total rework costs could have a high variation with a range from $0 \%$ to $75 \%$.

Josephson, et al. (2002) suggest that rework costs should be considered on three levels to obtain a comprehensive view:

- Direct costs: the cost of defect elimination for the defects found before or after handover.

- Checking costs: the costs of checks, inspections and return visits to complete defects.

- Prevention costs: the costs of preventive measures and the system.

There have been cases where indirect costs of rework were 22 times greater than the direct costs (Love and Edwards, 2004).

Considering rework as 'waste' of material, time and budget, which can be associated with the lack of quality control and /or the lack of collaboration through design and construction, urgent need for efficiently involving new approaches such as 'lean', in the housing supply chain is highlighted.

\section{LEAN APPROACH IN HOUSING SUPPLY CHAIN}

Lean thinking aims to increase value in every process step in production. The concept has been transferred to the construction industry from manufacturing principles, first by Koskela (1992). He termed the concept as 'Lean Construction (LC)'. Although the construction industry is very different from manufacturing, housing construction, as a unique sector in construction, provides the closest analogy to car production (Winch, 2003). The industrialised housing can be compared with car manufacturing regarding similarities exists in their production strategies, as suggested by Gann (1996) and Barlow, et al.(2003). Its distinctive features, including controllable production flow, high production volume (repetitiveness) and large inventory of work process, make the application of lean thinking favourable for the housing supply chain (Yu, et al., 2009).

The majority of the construction industry has failed to implement LC, and despite certain remarkable achievements, it has not been as prevalent in the construction practice and literature (Koskela, et al., 2012; Bolviken and Koskela, 2016). More specifically, Mossaman (2009) stated that lean has not been implemented in the UK because of fragmentation. Sub-contracting and fragmentation in construction means that there is little motivation for project teams to learn together as it is highly unlikely that they will work together again.

The housing construction industry has a large supply chain and is characterised by high levels of fragmentation. Harris (2013) has shown that for a typical large housing project (within a range of $£ 20$ to $£ 25$ million) the main contractor may be directly managing around 70 small enterprises as subcontracts. For a regional project, the subcontract size may be even smaller. This is clear evidence of the scale of fragmentation in the industry, which also confirms the extensive engagement of small medium size enterprises (SMEs) in the housing supply chain in the UK as subcontractors. 
There have been attempts by some clients to create opportunities for SMEs as subcontractors through partnering agreements, but these generally only involves the major players (Mossman 2009). To conduct a LC deployment research beyond some specific LC techniques, Tezel, et al. 2017 suggested to take into account the entire supply chain and sector context as well as project governance structure.

\section{ROOT CAUSES OF REWORK}

Traditionally, the source and cause of construction rework have mostly been considered as the responsibility of the main contractors. However, this is a simplistic view of the complex problem. Some of the rework problems handed to the site operatives are beyond the contractors control. Project designer, product manufacturer, contractor and subcontractors, materials handling, procurement and site construction practices can all contribute to the reduction of construction rework.

The focus in most house construction practices is on fixing the problems (that is, the faults in the particular house) at the end of the construction and before handing over to the client. However, if the source of the problem is not examined and the cause is not identified, there is no guarantee that the problem will not to be repeated in the next project.

Shammas-Toma, et al. (1996) classify the defects which appear during construction but are caused prior to construction, such as during the design process or at the point of production. Josephson and Hammarlund (1999) noted that operatives must have the necessary knowledge and motivation for correct execution of the task. Among several factors that contributed to higher defects levels, they highlighted 1) contractual pressures in terms of cost and time 2) late involvement of end user; and 3) delays in decisionmaking by client. Love, et al. (2009) indicated a 'lack of supply chain coordination' as one of the prominent factors causing defects.

The outcome of a comprehensive literature review (Fayek, et al. 2004; Mossman, 2009; Love, et al., 2010; and Arashpour, et al., 2014) on the contributors and root causes of rework in construction projects is presented in Figure 1.
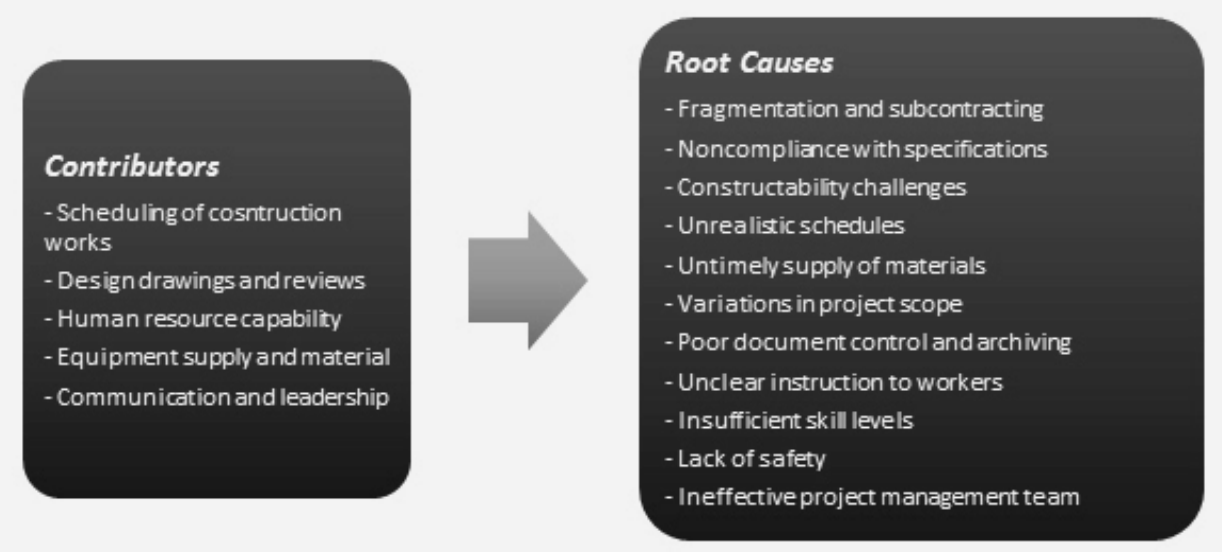

Figure 1: Contributors and root causes of rework in construction projects 
The research by Dissanayake et al 2003 also categorizes rework components into five main causes as below:

1- Human resource capability

2- Engineering and reviews

3- Leadership and communication

4- Construction Planning and scheduling

5- Material and equipment supply

Further research is suggested on the level of contribution in rework generation of the aforementioned categories. This can help researchers and industry to emphasis more on the most crucial category which contributes to the rework generation most.

\section{CURRENT PRACTICE FOR REWORK MINIMISATION}

Previous works on rework reduction and avoidance in construction projects have identified the following two key practices for construction organisations seeking to minimise rework:

- Rework reduction by using various measures at the early stages of the design process including standardisation and dimensional coordination, limitation of design modifications and provision of detailed designs (Poon, 2007).

- The use of prefabricated products to reduce rework generation on site, which consequently contributes to cost savings and higher quality (Love, et al., 2004; Zhang, et al., 2012).

Researchers have concluded that there is a gap between theory and practical implementation of the suggested practices for rework minimisation by construction firms.

Lingard et al. (2000) claimed that the attitude of being 'resistant to change' as part of the common culture in the construction industry is a major barrier to effective implementation of rework minimisation practices.

The study by Teo and Loose more (2001) indicates that the unique nature of each project, the fragmented character of the project organisations and poor coordination and integration between various participants are the main barriers for successful rework minimisation.

Academic conversations indicate that many barriers to efficient rework minimisation revolve around underlying behavioural and structural characteristics of the construction supply chain in general and SMEs as subcontractors in particular.

For further research, study on approaches for prevention of rework is suggested. Researchers have raised quite few suggestions, some approaches include visualizationenabled technologies such as: Modular construction, lean construction, constructability reviews between design and construction team, relationship based procurement method and most importantly utilising building information modelling (BIM). 


\section{REWORK WITHIN THE ENTIRE SUPPLY CHAIN}

Rework is being produced by the actions of the entire housing supply chain through design, manufacturing, demolition, construction, distribution and refurbishment. Reworks caused by various actors in the supply chain are different in terms of amounts, causes, composition and levels of integration. Each actor plays a role in reaching the minimum rework, but the actions and their relative contribution may vary in accordance with their ability to deliver. Significant reduction in rework will only be possible if they are assessed and managed within the entire supply chain.

The level of rework generated in a project is inevitably influenced by the attitude of key players (Faniran and Caban, 1998). As clients set the standards of quality to which the project team must comply, they normally have the greatest influence over rework minimisation practices. However, efforts for rework minimisation will not be successful if those downstream the supply chain do not buy-in to effective rework minimisation strategies (Dainty and Brooke, 2004; Teo and Loosemore, 2001). Within this argument, the fragmented and unstructured nature of the construction industry might be seen as a significant barrier to embedding the culture of rework minimisation within the entire supply chain.

Further study by London (2008) has identified a deeper level of complexity in the construction industry. He argued that although subcontractors may not work with the same suppliers or customers on every project, they typically are located within a cluster of professional networks, which are develop and maintained over several years. Thus, there is an indication that there are indeed long-term relationships among the various actors of the supply chain who have various degrees of influence over each other in their attitude and behaviour towards the adoption of efficient rework minimisation strategies. Therefore, it is of importance to gain a deeper knowledge of how this takes place throughout the supply chain that is specific to the housing sector. Consequently, greater opportunity for innovation to take place in rework minimisation will be provided.

\section{ENGAGEMENT OF SMES AS SUBCONTRACTORS IN THE LEAN HOUSING SUPPLY CHAIN}

Fragmentation and subcontracting in the construction industry act as an obstacle to the deployment of LC in general and rework minimisation in particular (Asefeso, 2014; Taggart, et al., 2014). It has been observed that, fragmentation and subcontracting in housing construction hinder the incentives for project participants to efficiently implement lean towards producing affordable quality housing.

In practice, subcontractors view the main contractor as their 'client' and they have little concern for the ultimate project customer and other subcontractors with whom they have to interact (Karim, et al., 2006). Defects often go unnoticed or are not communicated as the result of this lack of integration with other subcontractors. As a consequence, the impact of late defect detection can be multiplied (Koskela, et al., 2006).

SMEs are the largest group in the construction supply chain (Morton and Ross, 2008) engaging as subcontractors in housing projects. However, the engagement with subcontractors for LC and rework reduction has been limited to date. It has been reported 
that only large companies which are in the top $1 \%$ of companies by size in the UK have taken the lean pathway (Tezel, et al., 2017). Some of the general arguments regarding the lack of LC deployments and rework minimisation in smaller-sized enterprises (across the construction industry in general) have been found as follows:

- As an impeding factor for partnering for LC, there are the prevalent lack of trust between SMEs and their larger clients (Briscoe, et al., 2001).

- Normally, there is lack of spare resources at SMEs to invest in innovation (Alves et al., 2009).

- Efficient LC deployment and rework reduction should integrate SMEs into the process, to eventually reduce the transaction costs of the entire industry, and; not only the main contractor (Miller, et al., 2002).

- Large clients need to actively support SMEs regarding trainings and resources to develop capabilities in innovative approaches (Feng and Price, 2005).

- Generally, there is a lack of belief regarding the mutual benefits in LC and supply chain integration practices (Dainty, et al., 2001).

In the housing supply chain in the UK the SMEs have been chosen as subcontractors for short terms by the Tier 1 companies, often on the basis of minimum price with fixedpriced contracts. Moreover, most of the time contact with the main clients for process improvement efforts and rework minimisation is shaped and directed by Tier 1 clients, and subcontractors have rarely been in direct contact with the main clients. Due to the nature of work, the subcontractors have to implement their on-site operations in short working windows to prevent delays in the project and disruptions to the supply chain. Given this context, one of the main client's strategic aims is to efficiently implement rework minimisation strategies across the whole housing supply chain, including all the subcontractors. Therefore, it is essential to establish an efficient lean-based framework for the entire supply chain by embarking on the role of subcontractors and their engagement to rework minimisation practice. This can be achieved by a comprehensive study to understand the current condition and future directions of rework minimisation in the SMEs as subcontractors in the UK's housing supply chain.

\section{CONCLUSION}

This paper investigated the significant problem of rework generation in housing construction projects. The root causes of reworks were reviewed and it was concluded that the entire housing supply chain should be studied to accurately point the source of rework. This is necessary to avoid or minimise rework for future projects. Fragmentation and subcontracting was identified as one of the major causes of rework generation in the housing supply chain. An efficient lean-based framework to be used within the supply chain by embarking on the role of subcontractors and their engagement to rework minimisation needs to be established for an efficient lean housing supply chain. 


\section{REFERENCES}

Alves, T.D.C.L., Barros Neto, J.D.P., Heineck, L.F., Pereira, P.E. and Kemmer, S.L. (2009)."Incentives and Innovation to Sustain Lean Construction Implementation." In Proceedings of the 19th Annual IGLC Conference, Lima, Peru.

Arashpour, M. Wakefield, R., Blismas, N. and Lee, E.W.M. (2014). "Analysis of Disruptions Caused by Construction Field Rework on Productivity in Residential Projects", Journal of Construction Engineering and Management, 140(2), p. 4013053. doi: 10.1061/(ASCE)CO.1943-7862.0000804.

Asefeso, A. (2014).Lean in Construction: Key to improvements in time, cost and quality, AA Global Sourcing Ltd.

Barber, P., Graves, A., Hall, M., Sheath, D. and Tomkins, C.(2000)."Quality failure costs in civil engineering projects."International Journal of Quality \& Reliability Management, 17(4/5), pp.479-492.

Barlow, J., Childerhouse, P., Gann, D., and Hong-Minh, S. (2003)."Choice and delivery in housebuilding: Lessons from Japan for UK housebuilders."Building Research\&Information, 31(2), 134-145.

Bolviken, T. and Koskela, L., (2016)."Why hasn't Waste Reduction Conquered Construction?" In: Proc. 24th Ann. Conf. of the Int'l. Group for Lean Construction, Boston, MA, USA. Sect, 1 pp. 3 - 12.

Briscoe, G., Dainty, A.R. and Millett, S., (2001)."Construction Supply Chain Partnerships: Skills, Knowledge and Attitudinal Requirements." European Journal of Purchasing \& Supply Management, 7(4), pp.243-255.

Burati Jr, J.L., Farrington, J.J. and Ledbetter, W.B. (1992). "Causes of quality deviations in design and construction."Journal of construction engineering and management, 118(1), pp.34-49.

Dainty, A.R., Briscoe, G.H. and Millett, S.J. (2001). "Subcontractor Perspectives on Supply Chain Alliances."Construction Management \& Economics, 19(8), pp.841-848.

Dainty, A. and Brooke, R. (2004)."Towards improved construction waste minimisation: a need for improved supply chain integration?"Structural Survey, Vol. 22 Is: 1, pp. 2029.

Dissanayake, M., Fayek, A.R., Wolf, H. and Tol, A.V., Developing a standard for construction field rework assessment, ASCE, Construction Research Congress, pp 1-8

Egan J. 1998. Rethinking construction: the report of the Construction Task Force. London: Department of the Environment, Transport and the Regions.

Fayek, A.R., Dissanayake, M. and Campero, O.(2004). "Developing a standard methodology for measuring and classifying construction field rework."Canadian Journal of Civil Engineering, 31(6), pp.1077-1089.

Faniran, O.O. and Caban, G. (1998). "Minimising waste on construction project sites", Engineering Construction and Architectural Management, 5, Vol. 2, p. 183.

Ferng, J. and Price, A.D., (2005), "An Exploration of the Synergies between Six Sigma, Total Quality Management, Lean Construction and Sustainable Construction."International Journal of Six Sigma and Competitive Advantage, 1(2), pp.167-187. 
Gann, D.E. (1996)."Construction as a manufacturing process? Similarities and differences between industrialized housing and car production in Japan." Construction Management and Economics, 14, 437-450.

Harris, E.C., (2013).Supply Chain Analysis into the UK Construction Sector, Department of Business, Innovations and Skills, UK.

Hwang, B.G., Thomas, S.R., Haas, C.T. and Caldas, C.H. (2009)."Measuring the impact of rework on construction cost performance."Journal of Construction Engineering and Management, 135(3), 187-98.

Josephson, P.E. and Hammarlund, Y. (1999)."The causes and costs of defects in construction."Automation in Construction, 8(6), 681-7.

Josephson, P.E., Larsson, B. and Li, H. (2002)."Illustrative benchmarking rework and rework costs in Swedish construction industry."Journal of Management in Engineering, 18(2), 76-83.

Karim, K., Marosszeky, M. and Davis, S. (2006)."Managing subcontractor supply chain for quality in construction."Engineering, Construction and Architectural Management, 13 (1), 27-42.

Koskela, L., (1992).Application of the new Production Philosophy to Construction. Technical report 72, CIFE, Stanford University.

Koskela, L., Henrich, G., Owen, R. and Vrijhoef, R. (2006)."Theory based production and project management." Paper presented at the 3rd International Salford Centre for Research and Innovation (SCRI) symposium, Delft, Netherlands.

Koskela, L., Sacks, R. and Rooke, J. (2012)."A brief history of the concept of waste in production."Proceedings of the IGLC-20, San Diego, CA, US, 18-20, July, 2012.

Kumaraswamy, M.M. and Dissanayaka, S.M., (2000). "ISO 9000 and beyond: from a Hong Kong construction perspective."Construction Management \& Economics, 18(7), pp.783-796.

Lingard, H., Graham, P. and Smithers, G. (2000)."Employee perceptions of the solid waste management system operation in a large Australian contracting organisation: implications for company policy implementation."Construction Management and Economics, Vol. 18, No. 4, pp. 383-393.

London, K. (2008). Construction supply chain economics. London: Taylor \& Francis

Love, P.E.D. (2002)."Auditing the indirect consequences of rework in construction: a case based approach."Managerial Auditing Journal, 17(3), 138-46.

Love, P.E. D. and Li, H., (2000)."Quantifying the causes and costs of rework in construction."Construction Management and Economics, 18:4, 479-490.

Love, P.E.D. and Edwards, D.J. (2004)."Forensic project management: the underlying causes of rework in construction projects."Civil Engineering and Environmental Systems, 21(3), 207-28.

Love, P.E.D., Edwards, D.J., Smith, J. and Walker, D.H.T. (2009)."Divergence or congruence? A path model of rework for building and civil engineering projects."Journal of Performance of Construction Facilities, 23(6), 480-8.

Miller, C.J., Packham, G.A. and Thomas, B.C. (2002). "Harmonization between Main Contractors and Subcontractors: A Prerequisite for Lean Construction?"Journal of Construction Research, 3(1), pp.67-82. 
Morton, R. and Ross, A. (2008). Construction UK: Introduction to the industry. WileyBlackwell.

Mossman, Alan (2009). "There really is another way, if only he could stop ... for a moment and think of it - Why isn't the UK construction industry going lean with gusto?"Lean Construction Journal, pp 24 -36.

Pan, W., Gibb, A.G.F. and Dainty, A.R.J., (2008)."Leading UK house builders' utilisation of site modern methods of construction."Building Research \& Information, 36(1), pp. $56-67$.

Poon C.S. (2007)."Reducing construction waste."Waste Management, 27(12):1715-6.

Rogge, D.F., Cogliser, C., Alaman, H. and McCormack, S.(2001). An investigation of field rework in industrial construction. Rep. no. RR153, 11.

Serpell, A., De Solminihac, H. and Figari, C.(2000). "A general diagnosis of construction quality in Chile." In Proceedings of the Second International Conference of the CIB Task Group on Construction in Developing Countries,pp. 105-112.

Shammas-Toma, M., Seymour, D. and Clark, L. (1996)."The effectiveness of formal quality management systems in achieving the required cover in reinforced concrete."Construction Management and Economics, 14 (4), 353-64.

Simpeh, E.K., Ndihokubwayo, R., Love, P.E. and Thwala, W.D.(2015). "A rework probability model: a quantitative assessment of rework occurrence in construction projects."International Journal of Construction Management, 15(2), pp.109-116.

Sommerville, J.(2007). "Defects and rework in new build: an analysis of the phenomenon and drivers."Structural Survey, 25(5), pp.391-407.

Taggart, M., Koskela, L. and Rooke, J. (2014)."The role of the supply chain in the elimination and reduction of construction rework and defects: an action research approach."Construction Management and Economics, 32:7-8, 829-842.

Teo, M. and Loosemore, M. (2001)."A theory of waste behaviour in the construction industry."Construction Management and Economics, vol. 19, No. 7, pp. 741-51.

Tezel A., Koskela L., and Aziz Z. (2017)."Lean Construction in Small-Medium Sized Enterprises (SMEs): an Exploration of the Highways Supply Chain." In: LC3 2017 Volume II, Proceedings of the 25th Annual Conference of the International Group for Lean Construction, Heraklion, Greece, pp. 853-859.

Winch, G. M. (2003)."Models of manufacturing and the construction process: The genesis of reengineering construction."Building Research \& Information, 31(2), 107118.

Womack, J. and Jones, D. (2003).Lean Thinking: Banish Waste and Create Wealth in your Corporation. Simon \& Schuster Ltd, London.

Yu, H., Tweed, T., Al-Hussein, M. and Nasseri, R. (2009)."Development of Lean Model for House Construction Using Value Stream Mapping."Journal of Construction Engineering and Management, 135(8), 782-790.

Zhang, X. and Skitmore, M., 2012. Industrial housing in China: a coin with two sides. International Journal of Strategic Property Management, 16(2), pp.143-157. 